\title{
Antidiarrhoeal activity of fractions of aqueous extract of Mangifera indica L. leaves in castor oil-induced diarrhoeal female Wistar rats
}

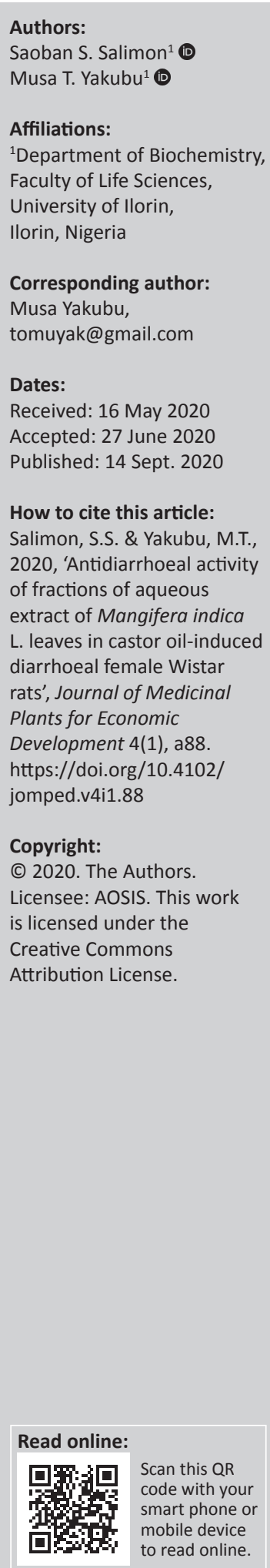

Background: The aqueous extract of Mangifera indica leaves (AEMIL) has been substantiated for its antidiarrhoeal activity without information on the antidiarrhoeal-rich solvent fraction.

Aim: This study evaluated the antidiarrhoeal activity of solvent-solvent fractions from $M$. indica leaves in female Wistar rats.

Setting: This is laboratory animal-based phytopharmacological investigation conducted at the University of Ilorin.

Methods: Aqueous extract of $M$. indica leaves was successfully fractionated to give ethyl acetate fraction (EAF), n-butanol fraction (NBF) and aqueous residual fraction (ARF). The fractions at 25,50 and $100 \mathrm{mg} / \mathrm{kg}$ body weight (bw) were screened for antidiarrhoeal activity. The antidiarrhoeal index (ADI) was also computed.

Results: Ethyl acetate fraction, NBF and ARF significantly $(p<0.05)$ extended the onset of diarrhoea, reduced fecal parameters (number, weight and water content of feaces and number of diarrhoeal feaces), masses and volumes of intestinal fluid, distance covered by charcoal meal, peristaltic index and its inhibition, with ARF exhibiting the most pronounced effects. The ADI at 25 and $100 \mathrm{mg} / \mathrm{kg}$ bw (equivalent doses of 14.09 and $56.3 \mathrm{mg} / \mathrm{kg} \mathrm{bw}$, respectively) of ARF which were 55.19 and 49.87 , respectively were similar to 48.50 produced by loperamide/ atropine sulphate. The ADI of 32.36 and 10.18 for $100 \mathrm{mg} / \mathrm{kg}$ bw each (equivalent of 26.41 and $17.24 \mathrm{mg} / \mathrm{kg} \mathrm{bw}$ ) of EAF and NBF respectively, were lower than that of loperamide/atropine sulphate (48.50).

Conclusion: Of all the fractions, the $25 \mathrm{mg} / \mathrm{kg}$ bw of ARF produced the most profound antidiarrhoeal activity via anti-motility and anti-secretory mechanisms.

Keywords: Anacardiaceae; antidiarrhoeal; anti-motility; anti-secretory; Mangifera indica.

\section{Introduction}

Diarrhoea is an alteration in bowel movement, characterised by increased water content, volume and frequency of stooling, usually occurring three or more times a day, whilst the frequent passing of loose 'pasty' stools or formed stools by breastfed babies is not regarded as diarrhoea (Omole et al. 2019). It is a major cause of morbidity and mortality affecting more children than adults (UNICEF 2010, 2019; Burton \& Singer 2014). It can also be a sequelae for irritable bowel syndrome, gastroenteritis, cholera, malaria and diabetes mellitus (Burton \& Singer 2014).

Globally, an annual incidence of about 1.7 billion childhood diarrhoeal episodes has been reported in humans, with mortality of 525000 children under the age of five (WHO 2017). Most of the deaths from diarrhoea occur amongst children aged less than 2 years living in South Asia and sub-Saharan Africa (UNICEF 2019). Of this, Nigeria accounts for an estimate of 150000 diarrhoeal deaths (Charyeva et al. 2015; Peter \& Umar 2018).

Management strategies of diarrhoea have been to prevent dehydration via the use of oral rehydration solutions, intravenous fluids, conventional drugs such as loperamide or its combination with simethicone and antibiotics such as azithromycin and ciprofloxacin. However, these options are now known to be accompanied by severe constipation, vomiting, uncomfortable fullness and pain of the stomach, fast or irregular heartbeat and occasionally syncope. In addition, because of the continuous escalation in the healthcare 
cost, perceived efficacy, the emergence of resistant pathogenic strains, potential to exhibit bioactivity through multiple mechanisms and financial austerity in major developing countries, the interest in natural productbased drug development needs to be revitalised. Therefore, exploring alternative and complementary options in medicinal plants for the management of diarrhoea will not be out of place.

Mangifera indica Linn. (family, Anacardiaceae) commonly known as mango in English and mangoro in Yoruba, mangwaro in Hausa and mangolo in Igbo languages of Nigeria grows mainly in Africa and all ecological zones of Nigeria. The leaves have been claimed to be used for managing diabetes mellitus, dysentery, cough, pains, jaundice, ulcer, hiccup, burns, scald and diarrhoea (Muruganandan et al. 2005; Ojewole 2005; Ojo et al. 2018). The ethyl acetate fractions of Spondias mombin and $M$. indica leaves have been reported to inhibit the activities of $\alpha$-amylase and $\alpha$-glucosidase (Ojo et al. 2018). Yakubu and Salimon (2015) reported that both the 25 and $50 \mathrm{mg} / \mathrm{kg}$ body weight (bw) of aqueous extract of M. indica leaves (AEMIL) prolonged the commencement of diarrhoea and decreased the number, water content, and weight of feaces as well as the number of diarrhoeal faeces, whilst there was no episode of diarrhoea in the $100 \mathrm{mg} / \mathrm{kg}$ bw of AEMIL-treated female Wistar rats. Also, AEMIL increased the activity of sodium-potassium adenosine triphosphatase $\left(\mathrm{Na}^{+} / \mathrm{K}^{+}\right.$-ATpase $)$and dose-dependently decreased the masses and volumes of the intestinal fluid as well as the distance covered by the charcoal meal. The study concluded that AEMIL exhibited antidiarrhoeal activity and attributed this to the presence of alkaloids, flavonoids, phenolics and saponins that have been reported to enhance the activity of the $\mathrm{Na}^{+} / \mathrm{K}^{+}$-ATPase. The report by Yakubu and Salimon (2015) however, did not provide any information on the effects of solvent-partitioned fractions of AEMIL on diarrhoea in female Wistar rats, an important step towards the in vivo bioactivity-guided isolation procedures that will lead to the isolation and characterisation of the bioactive agent(s).

Therefore, this study evaluated the antidiarrhoeal activity of the fractions of AEMIL in female Wistar rats.

\section{Materials and methods}

\section{Plant material and authentication}

The plant name Mangifera indica Linn, was checked on http://theplantlist.org and found to be accepted on 23 March 2012. Mangifera indica leaves were collected from the premises of the Senior Staff Quarters, University of Ilorin, located at Government Reserved Area of Ilorin (Global Positioning System: Latitude $8^{\circ} 29^{\prime 2} 28.485^{\prime \prime} \mathrm{N}$ and Longitude $\left.4^{\circ} 35^{\prime} 41.934^{\prime \prime E}\right)$, Kwara State, Nigeria. The plant was authenticated at the Herbarium Unit of the Department of Plant Biology, University of Ilorin and assigned a voucher number, UILH/001/1080.

\section{Experimental animals}

Healthy, female Wistar rats (Rattus norvegicus; average weight: $124.10 \mathrm{~g} \pm 3.08 \mathrm{~g}$ ) were procured from the Department of Pharmacology, Obafemi Awolowo University, Ile-Ife, Nigeria.

\section{Drugs and chemicals}

Castor oil, loperamide hydrochloride and atropine sulphate were manufactured by Bells Sons and Co. (Druggist) Ltd., (Southport, England); Lincoln Pharmaceuticals Ltd., (Gujarat, India); and Hubei Tianyo Pharmaceutical Industry Company Limited, (Dufu Alley, Fancheng District, Xiangyang, Hubei, China). Ethylacetate, n-butanol and diethyl ether were products of Emsure Merck, (Darmstadt, Germany); Lobal Chemie Laboratory Reagents and Fine Chemicals, Lobal Chemie Pvt. Ltd, (Mumbai, India); and British Drug House Chemicals Ltd., (Poole, England), respectively.

\section{Preparation of plant extract and solvent-solvent partitioning of aqueous extract of Mangifera indica leaves}

The oven-dried $\left(40^{\circ} \mathrm{C}\right)$, pulverised, fresh, $M$. indica leaves (300 g) were extracted in $3 \mathrm{~L}$ of distilled water. The resulting extract was lyophilised using a freeze dryer (Biobase Biodustry Co. Ltd., Shandong, China) to yield $21.12 \mathrm{~g}$, which corresponded to a percentage yield of $7.04 \%$ of the starting material. The methods described by Dhawan and Gupta (2017) were adopted for the solvent-solvent partitioning of AEMIL, with slight modifications. The solution of the extract was fractionated successively using ethyl acetate and n-butanol whilst also retaining the residue. The fractions obtained (ethyl acetate-, n-butanol- and residual fractions) were then evaporated to dryness at $40^{\circ} \mathrm{C}$ using a rotary evaporator (Eyela, N-N Series, Rikakikai Co. Ltd., Tokyo, Japan). The resulting fractions, ethyl acetate fraction (EAF), n-butanol fraction (NBF) and aqueous residual fraction (ARF) yielded $5.58 \mathrm{~g}, 3.62 \mathrm{~g}$ and $11.83 \mathrm{~g}$, respectively, of the starting material. The fractions were then reconstituted appropriately and used for the screening of antidiarrhoeal activity in the diarrhoeal models.

\section{Animal handling}

The female Wistar rats were kept in clean aluminium cages and maintained under well-ventilated house conditions (temperature: $27 \pm 2{ }^{\circ} \mathrm{C}$; photoperiod: about 12 hours light and dark cycle; relative humidity: $45 \%-55 \%$ ). The rats also had unrestricted access to rat pellets (Cap Feeds and Flours Mills Ltd, Ibadan, Oyo State, Nigeria) and clean tap water except where otherwise specified.

\section{Determination of antidiarrhoeal activity of the fractions of aqueous extract of Mangifera indica leaves}

\section{Castor oil-induced diarrhoeal model}

The model described by Sunil et al. (2001) was adopted with slight modification. The test animals were fasted (without food, but water) for $8 \mathrm{~h}$ prior to the commencement of 
the experiment. Each rat was placed in a cage, the floor of which was lined with blotting paper. Rats in the first (positive control) and second (negative control) groups were orally administered $1 \mathrm{~mL}$ corresponding to $2.0 \mathrm{mg} / \mathrm{kg}$ bw of loperamide hydrochloride and $1 \mathrm{ml}$ of distilled water, whilst the other test groups were administered equal volume corresponding to the equivalent doses of 25,50 and $100 \mathrm{mg} / \mathrm{kg}$ bw. These were $25 \mathrm{mg} / \mathrm{kg}$ bw (equivalent dose of $6.60 \mathrm{mg} / \mathrm{kg} \mathrm{bw}$ ), $50 \mathrm{mg} / \mathrm{kg}$ bw (equivalent dose of $13.20 \mathrm{mg} /$ $\mathrm{kg} \mathrm{bw}$ ) and $100 \mathrm{mg} / \mathrm{kg}$ bw (equivalent dose of $26.41 \mathrm{mg} / \mathrm{kg}$ $\mathrm{bw}$ ) of EAF; $25 \mathrm{mg} / \mathrm{kg}$ bw (equivalent dose of $4.31 \mathrm{mg} / \mathrm{kg}$ bw), $50 \mathrm{mg} / \mathrm{kg}$ bw (equivalent dose of $8.62 \mathrm{mg} / \mathrm{kg} \mathrm{bw}$ ) and $100 \mathrm{mg} / \mathrm{kg}$ bw (equivalent dose of $17.24 \mathrm{mg} / \mathrm{kg} \mathrm{bw}$ ) of NBF; and $25 \mathrm{mg} / \mathrm{kg}$ bw (equivalent dose of $14.09 \mathrm{mg} / \mathrm{kg} \mathrm{bw}$ ), $50 \mathrm{mg} / \mathrm{kg}$ bw (equivalent dose of $28.18 \mathrm{mg} / \mathrm{kg} \mathrm{bw}$ ) and $100 \mathrm{mg} / \mathrm{kg}$ bw (equivalent dose of $56.35 \mathrm{mg} / \mathrm{kg} \mathrm{bw}$ ) of ARF. At $30 \mathrm{~min}$ post-treatment, each rat was again treated with $1 \mathrm{~mL}$ of castor oil and the time between the administration of the oil and the appearance of the first diarrhoeal drop was noted. The severity of diarrhoea was determined every hour for a period of $4 \mathrm{~h}$ by monitoring the diarrhoeal drops on the pre-weighed blotting paper placed beneath the rat cages. The total number of faeces, diarrhoeal faeces and total weight of faeces excreted as well as the number of diarrhoeal faeces were expressed as an average of six determinations and compared with those of the controls. The percentage inhibition of diarrhoeal defecation in each group was computed at the end of $4 \mathrm{~h}$.

The equivalent doses of 25, 50 and $100 \mathrm{mg} / \mathrm{kg}$ bw were computed for each of the solvent-solvent fractions, according to Uwazie, Yakubu, Ashafa and Ajiboye (2020), using the following formula:

$$
\begin{aligned}
& \text { Dosage }(m g / k g b w)=\frac{\text { Solvent partitioned fraction }(g)}{\text { Partitioned extract }(g)} \times \\
& \text { Equivalent dose }(m g / k g b w)
\end{aligned}
$$

\section{Castor oil-induced enteropooling}

The procedure described by Havagiray, Ramesh and Sadhna (2004) was adopted for evaluating the inhibitory effects of the fractions on the accumulation of intraluminal fluid in the small intestine of the rats. The test animals were fasted for $8 \mathrm{~h}$ before the experiment. The rats in the positive control group received $1 \mathrm{~mL}$ of atropine sulphate corresponding to $1.0 \mathrm{mg} / \mathrm{kg}$ bw intramuscularly, whilst those negative control group received orally $1 \mathrm{~mL}$ of distilled water. Rats in the test groups received an equal volume corresponding to the equivalent doses of 25,50 and $100 \mathrm{mg} / \mathrm{kg}$ bw, which were $6.60,13.20$ and $26.41 \mathrm{mg} / \mathrm{kg}$ bw of EAF; 4.31, 8.62 and $17.24 \mathrm{mg} / \mathrm{kg}$ bw of NBF; and 14.09, 28.18 and $56.35 \mathrm{mg} / \mathrm{kg}$ bw of ARF. Immediately after these administrations, $1 \mathrm{~mL}$ of castor oil was administered orally to each rat in all of the groups. After $30 \mathrm{~min}$, the rats were sacrificed as described by Akanji and Yakubu (2000). The small intestine was excised and the intestinal contents were squeezed out into a measuring cylinder to obtain the volume and mass of the intestinal content. The inhibition of intestinal content according to Havagiray et al. (2004), was then computed using the following formula:

Inhibition of intestinal content $(\%)=$ Mass of intestinal fluid $(\mathrm{g})$

$\left(\frac{\text { Control }- \text { Treated }}{\text { Control }}\right) \times 100$

[Eqn 2]

\section{Gastrointestinal motility test}

Gastrointestinal motility was determined as described by Al-Taher (2008), with slight modification. Thirty minutes after the administration of $2 \%(\mathrm{v} / \mathrm{v})$ Tween-80, atropine sulphate and the various fractions of AEMIL (6.60, 13.20 and $26.41 \mathrm{mg} /$ $\mathrm{kg}$ bw of EAF; $4.31,8.62$ and $17.24 \mathrm{mg} / \mathrm{kg}$ bw of NBF; and $14.09,28.18$ and $56.35 \mathrm{mg} / \mathrm{kg}$ bw of ARF), $1 \mathrm{~mL}$ of castor oil was administered orally to the rats to induce diarrhoea. After 30 min of castor oil administration, all of the rats received orally $1 \mathrm{~mL}$ of charcoal meal marker $(10 \%$ charcoal suspension in $2 \%$ Tween- 80 ). All the rats were sacrificed after $30 \mathrm{~min}$ of administration of the charcoal meal marker; the small intestine was rapidly dissected out for careful inspection. The distance covered by the charcoal meal (DCM) plug from the pylorus to caecum was measured and expressed as a percentage of the total length of the small intestine (LSI). The peristaltic index (PI) for each rat was calculated, according to Al-Taher (2008) and Yakubu and Salimon (2005), as a percentage of the DCM relative to the LSI, that is:

$\mathrm{PI}=\frac{\mathrm{DCM}}{\mathrm{LSI}} \times 100$

[Eqn 3]

The percentage inhibition relative to the control was also computed using the following formula:

Percentage Inhibition $=$ Mean of distance travelled by marker

$\left(\frac{\text { Control }- \text { Treatment }}{\text { Control }}\right) \times 100$

[Eqn 4]

\section{Computation of the antidiarrhoeal index}

The combined effects of all of the EAF, NBF and ARF of AEMIL on the diarrhoeal models were computed and compared with their respective controls to obtain the antidiarrhoeal index (ADI) using the following formula:

$\mathrm{ADI}=\sqrt[3]{D_{\text {freq }} \times P_{\text {red }} \times I_{\text {red }}}$

[Eqn 5]

where $D_{\text {freq }}=$ Delay in emergence in relation to the control

$P_{\text {red }}=$ Reduction in peristaltic movement in relation to the control

$I_{\text {red }}=$ Reduction of intraluminal fluid content in relation to the control (Than et al. 1989). 


\section{Data analysis}

Data that were mean \pm standard error of mean (SEM) of six experiments were subjected to one-way analysis of variance and Tukey's post hoc test. The data were considered statistically significant at $p<0.05$ using GraphPad Prism version 6.01 (GraphPad Software, Inc., San Diego, California, United States).

\section{Ethical consideration}

Ethical approval to conduct the study was obtained from the Ethical Review Committee of the University of Ilorin (reference number: UERC/ASN/2017/916).

\section{Results}

\section{Effects of the aqueous extract of Mangifera indica leaves fractions on diarrhoea induced by castor oil}

The EAF, NBF and ARF exhibited varying degrees of effects on the faecal parameters of diarrhoeal rats that were induced by castor oil administration (Table 1). Although EAF, NBF and ARF extended the time of commencement of diarrhoea in the rats, the extension by the dose of $100 \mathrm{mg} /$ $\mathrm{kg}$ bw (equivalent dose of $56.34 \mathrm{mg} / \mathrm{kg} \mathrm{bw}$ ) of ARF was the most pronounced (from $5 \mathrm{~min}$ to $84 \mathrm{~min}$ ) (Table 1). Furthermore, the EAF, NBF and ARF significantly reduced $(p<0.05)$ the total number, weight and water content of faeces as well as the number of diarrhoeal faeces, with the most pronounced reduction exhibited by the diarrhoeal rats that received $100 \mathrm{mg} / \mathrm{kg}$ bw (equivalent dose of $56.35 \mathrm{mg} / \mathrm{kg} \mathrm{bw}$ ) of ARF. For each of the solvent fraction, the ARF at $100 \mathrm{mg} / \mathrm{kg}$ bw (equivalent dose of $56.35 \mathrm{mg} / \mathrm{kg}$ bw), EAF at $100 \mathrm{mg} / \mathrm{kg}$ bw (equivalent dose of $26.41 \mathrm{mg} /$ $\mathrm{kg} \mathrm{bw}$ ) and NBF at $50 \mathrm{mg} / \mathrm{kg}$ bw (equivalent dose of $8.62 \mathrm{mg} / \mathrm{kg} \mathrm{bw}$ ) produced the most significant reduction of the faecal parameters (Table 1). Similarly, the ARF at $100 \mathrm{mg} / \mathrm{kg}$ bw (equivalent dose of $56.35 \mathrm{mg} / \mathrm{kg} \mathrm{bw}$ ) produced the highest inhibition of defecation (93.34\%) of all the three fractions (Table 1), whereas the highest for $\mathrm{EAF}$ at $100 \mathrm{mg} / \mathrm{kg} \mathrm{bw}$ (equivalent dose of $26.41 \mathrm{mg} / \mathrm{kg}$ bw) and NBF at $50 \mathrm{mg} / \mathrm{kg}$ bw $(8.62 \mathrm{mg} / \mathrm{kg} \mathrm{bw})$ were $31.42 \%$ and $11.43 \%$, respectively (Table 1 ).

\section{Effects of the aqueous extract of Mangifera indica leaves fractions on enteropooling induced by castor oil}

The volume of the intestinal content and the mass of the intestinal fluid were significantly $(p<0.05)$ reduced by EAF, $\mathrm{NBF}$ and ARF, with the ARF at $25 \mathrm{mg} / \mathrm{kg}$ bw (equivalent dose of $14.09 \mathrm{mg} / \mathrm{kg} \mathrm{bw}$ ) producing the most pronounced reduction (Table 2). The reduction, however, did not compare well $(p>0.05)$ with those of atropine sulphatetreated diarrhoeal rats. In contrast, the most striking inhibition of intestinal fluid (45.20\%) amongst all the doses of the fractions was produced by the ARF at $25 \mathrm{mg} / \mathrm{kg}$ bw (equivalent dose of $14.09 \mathrm{mg} / \mathrm{kg} \mathrm{bw}$ ) (Table 2).

\section{Effects of the aqueous extract of Mangifera indica leaves fractions on charcoal meal transit time}

The distance covered by the charcoal meal from the pylorus to the caecum varied with the fractions of AEMIL (Table 3). Generally, the distance covered by the charcoal meal by all the fractions in the diarrhoeal rats was significantly $(p<0.05)$ lower when compared with that of distilled water-treated rats (Table 3). Similarly, the computed PI was also lower when compared with that of the distilled water-treated rats. Although the inhibition of peristalsis produced after the administration of EAF, NBF and ARF was generally higher than the distilled water-treated diarrhoeal rats, the inhibition of peristalsis for the ARF at $25 \mathrm{mg} / \mathrm{kg}$ bw (equivalent dose of

TABLE 1: Effects of the solvent-solvent fractions of aqueous extract of Mangifera indica leaves on castor oil-induced diarrhoea in female Wistar rats.

\begin{tabular}{|c|c|c|c|c|c|c|c|c|c|c|c|}
\hline \multirow{2}{*}{$\begin{array}{l}\begin{array}{l}\text { Faecal } \\
\text { parameters }\end{array} \\
\begin{array}{l}\text { Actual doses } \\
\text { (mg/kg body } \\
\text { weight) }\end{array}\end{array}$} & \multirow{2}{*}{$\begin{array}{c}\text { Loperamide } \\
2.0\end{array}$} & \multirow{2}{*}{$\begin{array}{c}\begin{array}{c}\text { Distilled } \\
\text { water }\end{array} \\
0\end{array}$} & \multicolumn{3}{|c|}{ Ethyl acetate fractions } & \multicolumn{3}{|c|}{ n-Butanol fractions } & \multicolumn{3}{|c|}{ Aqueous residual fractions } \\
\hline & & & 25 & 50 & 100 & 25 & 50 & 100 & 25 & 50 & 100 \\
\hline $\begin{array}{l}\text { Equivalent } \\
\text { doses (mg/kg } \\
\text { body weight) }\end{array}$ & 2.0 & 0 & 6.60 & 13.20 & 26.41 & 4.31 & 8.62 & 17.24 & 14.09 & 28.18 & 56.35 \\
\hline $\begin{array}{l}\text { Onset time } \\
\text { (minutes) }\end{array}$ & $46.03 \pm 2.51 \ddagger$ & $5.13 \pm 0.81 \dagger$ & $9.86 \pm 0.88 \S$ & $15.87 \pm 2.149$ & $20.55 \pm 2.07 \dagger \dagger$ & $15.65 \pm 1.33 \S$ & $24.17 \pm 1.95$ & $9.23 \pm 1.01 \dagger \dagger$ & $139.44 \pm 15.19 \S$ & $57.68 \pm 5.139$ & $83.51 \pm 7.04 \dagger \dagger$ \\
\hline $\begin{array}{l}\text { Total number of } \\
\text { faeces }\end{array}$ & $9.00 \pm 0.71 \$$ & $12.25 \pm 0.48 \dagger$ & $11.75 \pm 0.85 \dagger$ & $8.75 \pm 0.25$ & $8.00 \pm 0.41 \%$ & $12.50 \pm 1.04 \dagger$ & $10.25 \pm 0.25 \S$ & $10.67 \pm 1.20 \div \S$ & $1.75 \pm 0.63 \S$ & $7.00 \pm 0.719$ & $2.33 \pm 0.33 \dagger \dagger$ \\
\hline $\begin{array}{l}\text { Number of } \\
\text { diarrhoeal faeces }\end{array}$ & $3.75 \pm 0.63 \ddagger$ & $8.75 \pm 0.38 \dagger$ & $8.75 \pm 0.48 \dagger$ & $6.50 \pm 0.51 \S$ & $6.00 \pm 0.41 \S$ & $10.00 \pm 0.41 \dagger$ & $7.75 \pm 0.25 \dagger$ & $8.00 \pm 1.00 \dagger$ & $0.50 \pm 0.19 \S$ & $4.15 \pm 0.23 \ddagger$ & $0.32 \pm 0.03 \S$ \\
\hline $\begin{array}{l}\text { Weight of } \\
\text { faeces }(\mathrm{g})\end{array}$ & $3.19 \pm 0.53 \$$ & $6.61 \pm 0.44 \dagger$ & $5.88 \pm 0.37 \dagger$ & $5.25 \pm 0.29 \S$ & $4.60 \pm 0.279$ & $6.74 \pm 0.15 \dagger$ & $5.93 \pm 0.17 \S$ & $6.11 \pm 0.51 \S$ & $0.14 \pm 0.01 \S$ & $3.72 \pm 0.27 \$$ & $0.19 \pm 0.06 \S$ \\
\hline $\begin{array}{l}\text { Water content } \\
\text { of faeces }(\mathrm{mL})\end{array}$ & $1.51 \pm 0.29 \ddagger$ & $4.78 \pm 0.23 \dagger$ & $4.47 \pm 0.25 \dagger$ & $2.91 \pm 0.12 \S$ & $3.07 \pm 0.12 \S$ & $4.61 \pm 0.18 \dagger$ & $4.13 \pm 0.13 \S$ & $3.58 \pm 0.19 \S$ & $0.02 \pm 0.00 \S$ & $2.50 \pm 0.139$ & $0.04 \pm 0.00 \S$ \\
\hline $\begin{array}{l}\text { Inhibition of } \\
\text { defecation (\%) }\end{array}$ & $57.14 \pm 0.00$ & $0.00 \pm 0.00$ & $0.00 \pm 0.00$ & $25.71 \pm 0.00$ & $31.42 \pm 0.00$ & $0.00 \pm 0.00$ & $11.43 \pm 0.00$ & $8.57 \pm 0.00$ & $94.29 \pm 0.00$ & $52.57 \pm 0.00$ & $96.34 \pm 0.00$ \\
\hline
\end{tabular}

Note: Values are mean \pm SEM of six experiments.

SEM, standard error of mean.

$\dagger$, Loperamide-treated control.

$\$$. Each parameter $(p<0.05)$.

$\S, \mathbb{\uparrow}, \dagger \dagger$, Test values are different from that of the distilled water-treated control. 
TABLE 2: Effects of the solvent-solvent fractions of aqueous extract of Mangifera indica leaves on castor oil-induced enteropooling in female Wistar rats.

\begin{tabular}{|c|c|c|c|c|c|c|c|c|c|c|c|}
\hline \multirow{2}{*}{$\begin{array}{l}\begin{array}{l}\text { Faecal } \\
\text { parameters }\end{array} \\
\text { Actual doses } \\
\text { (mg/kg body } \\
\text { weight) }\end{array}$} & \multirow{2}{*}{$\begin{array}{c}\begin{array}{c}\text { Atropine } \\
\text { sulphate }\end{array} \\
1.0\end{array}$} & \multirow{2}{*}{$\begin{array}{c}\begin{array}{c}\text { Distilled } \\
\text { water }\end{array} \\
0\end{array}$} & \multicolumn{3}{|c|}{ Ethyl acetate fractions } & \multicolumn{3}{|c|}{ n-Butanol fractions } & \multicolumn{3}{|c|}{ Aqueous residual fractions } \\
\hline & & & 25 & 50 & 100 & 25 & 50 & 100 & 25 & 50 & 100 \\
\hline $\begin{array}{l}\text { Equivalent doses } \\
\text { (mg/kg body } \\
\text { weight) }\end{array}$ & 1.0 & 0 & 6.60 & 13.20 & 26.41 & 4.31 & 8.62 & 17.24 & 14.09 & 28.18 & 56.35 \\
\hline $\begin{array}{l}\text { Mass of intestinal } \\
\text { contents (g) }\end{array}$ & $2.31 \pm 0.15 \ddagger$ & $5.73 \pm 0.81 \dagger$ & $3.88 \pm 0.06 \S$ & $3.91 \pm 0.03 \S$ & $3.72 \pm 0.16 \S$ & $4.95 \pm 0.19 \dagger$ & $6.03 \pm 0.34 \dagger$ & $4.28 \pm 0.36 \S$ & $3.14 \pm 0.01 \S$ & $3.75 \pm 0.229$ & $3.33 \pm 0.06 \S$ \\
\hline $\begin{array}{l}\text { Volume of intestinal } \\
\text { fluid }(m L)\end{array}$ & $1.81 \pm 0.29 \ddagger$ & $4.60 \pm 0.23 \dagger$ & $3.00 \pm 0.07 \S$ & $3.15 \pm 0.119$ & $2.89 \pm 0.109$ & $4.00 \pm 0.10 \S$ & $4.50 \pm 0.229$ & $3.77 \pm 0.18$ & $2.05 \pm 0.07 \S$ & $2.50 \pm 0.119$ & $2.44 \pm 0.10^{9}$ \\
\hline $\begin{array}{l}\text { Inhibition of } \\
\text { intestinal fluid (\%) }\end{array}$ & $59.69 \pm 0.00$ & $0.00 \pm 0.00$ & $32.29 \pm 0.00$ & $31.76 \pm 0.00$ & $35.08 \pm 0.00$ & $13.61 \pm 0.00$ & $0.00 \pm 0.00$ & $25.31 \pm 0.00$ & $45.20 \pm 0.00$ & $34.56 \pm 0.00$ & $41.88 \pm 0.00$ \\
\hline
\end{tabular}

Note: Values are mean \pm SEM of six experiments.

SEM, standard error of mean.

$\dagger$, Atropine sulphate-treated control.

$\$$ Each parameter $(p<0.05)$.

§., Test values are different from that of the distilled water-treated control.

TABLE 3: Effects of the solvent-solvent fractions of aqueous extract of Mangifera indica leaves on gastrointestinal motility of the female Wistar rats.

\begin{tabular}{|c|c|c|c|c|c|c|c|c|c|c|c|}
\hline \multirow{2}{*}{$\begin{array}{l}\begin{array}{l}\text { Faecal } \\
\text { parameters }\end{array} \\
\text { Actual doses } \\
\text { (mg/kg body } \\
\text { weight) }\end{array}$} & \multirow{2}{*}{$\begin{array}{c}\begin{array}{c}\text { Atropine } \\
\text { sulphate }\end{array} \\
1.0\end{array}$} & \multirow{2}{*}{$\begin{array}{c}\text { Distilled } \\
\text { water }\end{array}$} & \multicolumn{3}{|c|}{ Ethyl acetate fractions } & \multicolumn{3}{|c|}{ n-Butanol fractions } & \multicolumn{3}{|c|}{ Aqueous residual fractions } \\
\hline & & & 25 & 50 & 100 & 25 & 50 & 100 & 25 & 50 & 100 \\
\hline $\begin{array}{l}\text { Equivalent } \\
\text { doses (mg/kg } \\
\text { body weight) }\end{array}$ & 1.0 & 0 & 6.60 & 13.20 & 26.41 & 4.31 & 8.62 & 17.24 & 14.09 & 28.18 & 56.35 \\
\hline $\begin{array}{l}\text { Length of } \\
\text { small intestine } \\
\left(\mathrm{cm}^{3}\right)\end{array}$ & $94.03 \pm 2.50 \%$ & $87.15 \pm 0.90 \dagger$ & $88.52 \pm 2.11 \dagger$ & $89.95 \pm 1.90 \dagger$ & $88.40 \pm 2.00 \dagger$ & $92.12 \pm 1.33 *$ & $95.07 \pm 4.95 \%$ & $88.70 \pm 3.25 \dagger$ & $89.74 \pm 3.05+\%$ & $92.15 \pm 6.10 \%$ & $93.12 \pm 4.09 \%$ \\
\hline $\begin{array}{l}\text { Distance } \\
\text { travelled by } \\
\text { charcoal } \\
\text { meal }\left(\mathrm{cm}^{3}\right)\end{array}$ & $56.00 \pm 2.28 *$ & $84.15 \pm 3.11 \dagger$ & $66.67 \pm 1.15$ & $73.41 \pm 3.06 \S$ & $57.13 \pm 4.19 \ddagger$ & $73.15 \pm 1.20$ & $75.02 \pm 3.91 \S$ & $80.05 \pm 1.77+$ & $50.67 \pm 2.17 \ddagger$ & $71.22 \pm 5.81 \S$ & $58.29 \pm 2.08$ \\
\hline $\begin{array}{l}\text { Peristaltic } \\
\text { index }(\%)\end{array}$ & $59.56 \pm 0.01$ & $96.56 \pm 0.05$ & $75.32 \pm 0.10$ & $81.61 \pm 0.02$ & $64.63 \pm 0.01$ & $79.41 \pm 0.07$ & $78.91 \pm 0.05$ & $90.25 \pm 0.01$ & $56.46 \pm 0.01$ & $77.29 \pm 0.03$ & $62.60 \pm 0.02$ \\
\hline $\begin{array}{l}\text { Inhibition of } \\
\text { peristalsis (\%) }\end{array}$ & $33.45 \pm 0.00$ & $0.00 \pm 0.00$ & $20.77 \pm 0.00$ & $12.76 \pm 0.00$ & $30.73 \pm 0.00$ & $13.07 \pm 0.00$ & $10.85 \pm 0.00$ & $4.87 \pm 0.00$ & $39.79 \pm 0.00$ & $15.37 \pm 0.00$ & $30.73 \pm 0.00$ \\
\hline
\end{tabular}

Note: Values are mean \pm SEM of six experiments.

SEM, standard error of mean.

$\dagger, \downarrow$, Across the rows for each parameter are significantly different at $p<0.05$

$\S, \boldsymbol{\uparrow}, \dagger \dagger$, Test values are different from that of the distilled water-treated control, $\dagger$ and $\uparrow$

TABLE 4: Antidiarrhoeal index of the fractions of aqueous extract of Mangifera indica leaves.

\begin{tabular}{lllll}
\hline Solvent-solvent fractions & $\begin{array}{l}\text { Loperamide/atropine } \\
\text { sulphate }\end{array}$ & Distilled water & Antidiarrhoeal index & \\
\hline $\begin{array}{l}\text { Actual dose } \\
\text { (mg/kg body weight) }\end{array}$ & $2 / 1$ & 0 & 25 & 50 \\
Ethyl acetate & 48.50 & 0.00 & 0.00 & 22.72 \\
n-butanol & 48.50 & 0.00 & 0.00 & 32.36 \\
Residual & 48.50 & 0.00 & 55.19 & 100 \\
\hline
\end{tabular}

Note: Equivalent doses ( $\mathrm{mg} / \mathrm{kg}$ body weight).

Ethyl acetate: Loperamide/atropine sulphate $=6.60$; distilled water $=13.20$; antidiarrhoeal index $=26.41$.

n-Butanol: Loperamide/atropine sulphate $=4.31$; distilled water $=8.62$; antidiarrhoeal index $=17.25$.

Residual: Loperamide/atropine sulphate $=14.09 ;$ distilled water $=28.18$; antidiarrhoeal index $=56.35$

$14.09 \mathrm{mg} / \mathrm{kg} \mathrm{bw}$ ) was higher than that of the atropine-treated diarrhoeal rats (Table 3).

\section{Antidiarrhoeal index of the aqueous extract of Mangifera indica leaves fractions}

The computed ADI of the fractions of AEMIL was higher than that of distilled water-treated diarrhoeal rats (Table 4). However, compared with the combination of the reference drugs (loperamide/atropine sulphate), the ADI of the ARF at $25 \mathrm{mg} / \mathrm{kg}$ bw (equivalent dose of $14.09 \mathrm{mg} / \mathrm{kg} \mathrm{bw}$; ADI of 55.15) and $100 \mathrm{mg} / \mathrm{kg} \mathrm{bw}$ (equivalent dose of $56.35 \mathrm{mg} / \mathrm{kg}$ bw; ADI of 49.87) were higher than that of the loperamide/atropine sulphate (48.50) (Table 4).

\section{Discussion}

The use of plants or plant products is usually perceived to be efficacious against myriads of ailments, some of which are without scientific credence to substantiate or refute such claims. The preliminary pharmacological screening of crude extracts of medicinal plants, which is a step towards the successful isolation of bioactive principles, will serve as lead for drug development and promote conservation and sustainability of ancient knowledge. 
The findings of this study on castor oil-induced diarrhoea suggest that all the fractions (EAF, NBF and ARF) of AEMIL at varying doses delayed the onset of diarrhoea and reduced the episodes of the disease. However, the ARF at $100 \mathrm{mg} / \mathrm{kg}$ bw (equivalent dose of $56.35 \mathrm{mg} / \mathrm{kg} \mathrm{bw}$ ) exhibited the most profound antidiarrhoeal activity, with $96.34 \%$ inhibition of defecation and $84 \mathrm{~min}$ delay in the onset of diarrhoea. This outcome was in line with the previous findings of Yakubu and Salimon (2015) after the administration of AEMIL to castor oil-induced diarrhoeal female Wistar rats.

During diarrhoea, there is an increased production of secretagogues (such as prostaglandins, histamines and acetylcholine), which promote secretion over the reabsorption process, thus leading to a collection of fluid in the intestinal area (Sebai et al. 2014). The EAF, NBF and ARF of AEMIL stimulated the inhibition of the castor oil-induced enteropooling as evidenced by the reduction in the weight and volume of intestinal fluid content. Consistently, the ARF exhibited the most striking inhibition of hypersecretion, namely, reduced secretion and increased absorption of water and electrolyte in the small intestine (Shah 2004). This implies that the ARF contained some appreciable amount of bioactive compounds, which eventually subdued the production of secretagogues. The anti-enteropooling activity exhibited by the ARF at $25 \mathrm{mg} / \mathrm{kg}$ bw (equivalent dose of $14.09 \mathrm{mg} / \mathrm{kg} \mathrm{bw}$ ) in the present study compared well with the previous finding of Yakubu and Salimon (2015) in terms of volume and masses of the fluid in the small intestine, but the inhibition of intestinal fluid accumulation (45.20\%) was not as high $(66.45 \%)$ as that reported by Yakubu and Salimon (2015). The factors responsible for this large difference in the computed inhibition of intestinal fluid are not immediately known, but may be connected with the extraction process adopted in the present study.

An increase in intestinal propulsive movement leads to a short reabsorption time, which progresses into diarrhoea. The trend in suppression of charcoal meal movement in the intestinal transit model was similar to those of the antienteropooling and antidiarrhoeal models. The drop in the PI by the $100 \mathrm{mg} / \mathrm{kg}$ bw of EAF (equivalent of $24.61 \mathrm{mg} / \mathrm{kg} \mathrm{bw}$ ) and ARF (equivalent dose of $56.35 \mathrm{mg} / \mathrm{kg} \mathrm{bw}$ ) in a manner similar to the atropine sulphate corroborates the anti-motility effects of the fractions at this dose. Also, it is noteworthy to emphasise that the most profound reduction in the PI was exhibited by the ARF at $25 \mathrm{mg} / \mathrm{kg}$ bw (equivalent of $14.09 \mathrm{mg} / \mathrm{kg} \mathrm{bw}$ ) as evidenced from the inhibition of peristalsis, which was the highest amongst all the treatment groups including the atropine sulphate-treated rats. All these consistently emphasise the anti-motility effect of the ARF at $25 \mathrm{mg} / \mathrm{kg}$ bw.

Antidiarrhoeal index denotes the combined effects of all the diarrhoeal components in a given model such that a higher ADI connotes a better efficacy and well-rounded action against diarrhoea (Prasad et al. 2014). The current study indicates that ARF produced the highest ADI of all the fractions and compared well with that of loperamide hydrochloride/atropine sulphate. Expectedly, the NBF that had little or no activity in all of the diarrhoeal models exhibited the least ADI. This implies that the antidiarrhoeal principles of AEMIL are most abundant in the ARF.

\section{Conclusion}

This study concluded that ARF exhibited the most profound antidiarrhoeal activity in AEMIL and acted via anti-secretory and anti-motility mechanisms as evidenced by the decrease in water content and inhibition of peristalsis.

\section{Acknowledgements}

The authors appreciate late Dr T.O. Ajiboye for his technical support during the fractionation of the plant extract.

\section{Competing interests}

The authors have declared that no competing interest exists.

\section{Authors' contributions}

M.T.Y. designed the work and proofread the manuscript for intellectual content. S.S.S. designed the work, gathered the data, conducted the statistical analysis and drafted the manuscript. Both authors approved the final manuscript to be published in the journal.

\section{Funding information}

This research received no specific grant from any funding agency in the public, commercial or not-for-profit sectors.

\section{Data availability statement}

Data sharing is applicable to this article as new data were created or analysed in this study.

\section{Disclaimer}

The views and opinions expressed in this article are those of the authors and do not necessarily reflect the official policy or position of any affiliated agency of the authors.

\section{References}

Akanji, M.A. \& Yakubu, M.T., 2000, ' $\alpha$-Tocopherol protects against metabisulphiteinduced tissue damage in rats', Nigerian Journal of Biochemistry and Molecula Biology 15(2), 179-183.

Al-Taher, A.Y., 2008, 'Possible antidiarrhoeal effect of the date palm (Phoenix dactylifera L.) spathe aqueous extract in rats', Journal of King Saudi UniversitySciences 9(1), 131-138.

Burton, E.C. \& Singer, N.A., 2014, 'Pediatric natural deaths', in R.A. Collins \& R.W. Byard (eds.), Forensic pathology of infancy and childhood, pp. 855-898, Springer, New York, NY.

Charyeva, Z., Cannon, M., Oguntunde, O., Garba, A.M., Sambisa, W., Bassi, A.P. et al 2015, 'Reducing the burden of diarrhea among children under five years old: Lessons learned from oral rehydration therapy corner program implementation in Northern Nigeria', Journal of Health, Population, and Nutrition 34(4). https://doi. org/10.1186/s41043-015-0005-1 
Dhawan, D. \& Gupta, J., 2017, 'Comparison of different solvents for phytochemical extraction potential from Datura metel plant leaves', International Journal of Biological Chemistry 11(1), 17-22. https://doi.org/10.3923/ijbc.2017.17.22

Havagiray, R., Ramesh, C. \& Sadhna, K., 2004, 'Study of antidiarrhoeal activity of Calotropis gigantea R.B.R. in experimental animals', Journal of Pharmaceutical Sciences 7(1), 70-75.

Muruganandan, K., Srinivasan, S., Gupta, P.K. \& Gupta, J.L., 2005, 'Effect of mangiferin on hyperglycemia and atherogenicity in streptozotocin-diabetic rats', Journal of Ethnopharmacology 97(3), 497-501. https://doi.org/10.1016/j. jep.2004.12.010

Ojewole, J.A., 2005, 'Anti-inflammatory, analgesic and hypoglycemic effects of Mangifera indica Linn. (Anacardiaceae) stem-bark aqueous extract', Methods and Findings in Experimental and Clinical Pharmacology 27(8), 547-554. https://doi org/10.1358/mf.2005.27.8.928308

Ojo, O.A., Afon, A.A., Ojo, A.B., Ajiboye, B.O., Oyinloye, B.E. \& Kappo, A.P., 2018, 'Inhibitory effects of solvent-partitioned fractions of two Nigerian herbs (Spondias mombin Linn. and Mangifera indica L.) on $\alpha$-amylase and $\alpha$-glucosidase', Antioxidants 7(6), 73. https://doi.org/10.3390/antiox7060073

Omole, V.N. Wamyil-Mshelia, TM. Nmadu, G.A., Usman, N.O., Andeyantso, E.A. \& Adiri, F., 2019, 'Knowledge, attitude and practice of home management of Adiri, F., 2019, 'Knowledge, attitude and practice of home management of
diarrhoea among mothers of under-fives in Samaru, Kaduna State, Nigeria', Port Harcourt Medical Journal 13(1), 19-25.

Peter, A.K. \& Umar, U., 2018, 'Combating diarrhoea in Nigeria: The way forward', Journal of Microbiology \& Experimentation 6(4), 191-197. https://doi.org/ 10.15406/jmen.2018.06.00213

Prasad, S.K., Laloo, D., Kumar, R., Sahu, A.N. \& Hemalatha, S., 2014, 'Antidiarrhoeal evaluation of rhizomes of Cryptocoryne spiralis Fisch. ex Wydler: Antimotility and antisecretory effects', Indian Journal of Experimental Biology 52(2), 139-146.
Sebai, H., Jabri, M.A., Souli, A., Rtibi, K., Selmi, S., Tebourbi, O. et al., 2014 'Antidiarrheal and antioxidant activities of chamomile (Matricaria recutita L.) decoction extract in rats', Journal of Ethnopharmacology 152(2), 327-332. https:// decoction extract in rats', Journal of
doi.org/10.1016/j.jep.2014.01.015

Shah, S., 2004, 'Evaluation of diarrhea: The challenge continues! Part-1', Indian Journal of Medical Sciences 58(2), 75-78.

Sunil, B., Bedi, K., Singla, A. \& Johri, R., 2001, 'Antidiarrhoeal activity of piperine in mice', Planta Medica 67(3), 284-287. https://doi.org/10.1055/s-2001-11999

Than, A., Kulkarni, H.J., Hmone, W. \& Tha, S.J., 1989, 'Anti-diarrhoeal efficacy of some Burmese indigenous drug formulations in experimental diarrhoeal test models', International Journal of Crude Drug Research 27(4), 195-200. https://doi. org/10.3109/13880208909116903

UNICEF, 2010, 'Diarrhoea: Why children are still dying and what can be done, viewed 7 September 2017, from https://www.unicef.org/media/files/Final_Diarrhoea_ Report_October_2009_final.pdf.

UNICEF, 2019, Diarrhoea disease: UNICEF data, viewed 16 June 2020, from https:// data.unicef.org/topic/child-health/diarrhoeal-disease/.

Uwazie, N.J., Yakubu, M.T., Ashafa, A.O.T. \& Ajiboye, T.O., 2020. Identification and characterization of anti-diabetic principle in Senna alata flower using alloxaninduced diabetic male Wistar rats. Journal of Ethnopharmacology 261. https:// doi.org/10.1016/j.jep.2020.112997.

WHO, 2017, Essential medicines and health products information portal, viewed 29 October 2017 from http://apps.who.int/medicinedocs/en/d/Js4950e/2.4.html

Yakubu, M.T. \& Salimon, S.S., 2015, 'Antidiarrhoeal activity of aqueous extract of Mangifera indica L. leaves in female albino rats', Journal of Ethnopharmacology 163, 135-141. https://doi.org/10.1016/j.jep.2014.12.060 